\title{
Molecular Properties of a Granulocyte/Macrophage Colony- Stimulating Factor Obtained from the Serum-Free Culture of Yoshida Sarcoma Cell Line YSSF-212T
}

\author{
Tadao Ohno and Mikio Shikita \\ National Institute of Radiological Sciences, Anagawa 4-Chome, 9-1, Chiba-shi \\ 260, Japan
}

\begin{abstract}
A granulocyte/macrophage colony-stimulating factor (Peak-1 CSF) was partially purified from the medium of a serum-free culture of Yoshida sarcoma cells (Line YSSF-212T). Its elution position in gel-filtration chromatography corresponded to a molecular weight of about 22,000 . The factor had an isoelectric point at $\mathrm{pH} 4.5$ and a sedimentation coefficient of $2.3 \mathrm{~S}$. The major part of its activity was not bound by Concanavalin ASepharose. Although CSF activity behaved as a single component in the gel-filtration and isoelectrofocussing procedures, subsequently it was resolved into two species by preparative discontinuous polyacrylamide gel-electrophoresis. This resolution indicates microheterogeneity of the CSF molecule. Oxidation with periodate readily inactivated L.P3-cell CSF, but the YSSF-cell CSF was fairly resistant. Moreover, titration with anti-L cell CSF serum showed a definite difference between L·P3-cell CSF and YSSF-cell CSF.
\end{abstract}

The genealogy of blood cells involves bipotential myeloid stem cells that can develop into a lineage of neutrophilic granulocytes or a lineage of monocyte/macrophages $(11,19)$. This development is controlled by three different classes of humoral regulators, probably all of which are sialoglycoproteins. The first is the granulocytemacrophage colony-stimulating factor $(\mathrm{GM}-\mathrm{CSF})(3,5,6,8,9,17,22,30,33)$ that produces both granulocytes and macrophages from bipotential stem cells. The two other classes of CSF are the granulocyte colony-stimulating factor (G-CSF) $(4,23$, $34,35)$ and the macrophage colony-stimulating factor (M-CSF or CSF-1) $(1,13$, $20,28,29)$. The former acts on stem cells to produce mainly granulocytes, whereas the latter produces mainly macrophages from the stem cells.

These regulators appear to be produced locally in hematopoietic tissues $(10,15)$ and to perform their functions in the area in which they are produced (24). In addition to hematopoietic tissues, many other tissues contain cells (presumably macrophages and lymphocytes) capable of producing myelopoietic regulators such as those described above $(18,21,25)$. The entire mechanism of humoral regulation of myelopoiesis has yet to be determined, and detailed studies are needed.

Abbreviations used: GM-CSF, granulocyte-macrophage colony-stimulating factor; G-CSF, granulocyte colony-stimulating factor; M-CSF, macrophage colony-stimulating factor; CM, conditioned medium; Con A, Concanavalin A; Peak-1 CSF, the first peak CSF from DEAE-cellulose column chromatography. 
Previously, we reported (22) that Yoshida sarcoma cells (Line YSSF-212T) derived from a rat produce a CSF that can promote formation of granulocyte colonies in both human and murine bone marrow cell cultures. The YSSF-cell CSF attracted our attention because of its activity beyond species specificity. The molecular properties of the YSSF-cell CSF reported here resemble those of RSP-2.P3 cell CSF (30) and markedly differ from those of L·P3-cell CSF $(29,31)$.

\section{MATERIALS AND METHODS}

Cells. Yoshida sarcoma cells (Line YSSF-212T) basically were cultured as reported previously (22). Cells were suspended in a serum-free medium (RITC-1000PA) (36) at an initial density of $5 \times 10^{4} / \mathrm{ml}$, then 200 - $\mathrm{ml}$ samples were cultured for 9 days in 2-liter roller bottles at $37^{\circ} \mathrm{C}$.

Purification of Peak-1 CSF. About $8,600 \mathrm{ml}$ of the cell-conditioned medium was centrifuged at $1000 \times \mathrm{g}$ for $15 \mathrm{~min}$, then the supernatant was brought to $90 \%$ saturation with ammonium sulphate. The resulting precipitate (about $10 \mathrm{~g}$ protein) was taken by centrifugation and dialyzed against $2 \mathrm{mM}$ phosphate buffer of $\mathrm{pH}$ 6.5. The dialyzate was chromatographed on a DEAE-cellulose column $(6 \times 23 \mathrm{~cm})$ in two portions. After washing the column with 2.5 liters of $10 \mathrm{mM}$ Na phosphate $/ 25 \mathrm{mM} \mathrm{NaCl}(\mathrm{pH} 6.5)$ then with $350 \mathrm{ml}$ of $10 \mathrm{mM} \mathrm{Na}$ phosphate $/ 50 \mathrm{mM} \mathrm{NaCl}$, it was washed again with one liter of the latter phosphate-saline solution. The eluate (Peak-1 CSF) was concentrated to $7.3 \mathrm{ml}$ by a PM-10 membrane (Amicon), then $6.0 \mathrm{ml}$ of the $7.3 \mathrm{ml}$ was applied to a column of Ultro-gel AcA44 $(2.5 \times 100 \mathrm{~cm})$ that had been equilibrated with $10 \mathrm{mM}$ Na-phosphate $(\mathrm{pH} 7.4) / 150 \mathrm{mM}$ $\mathrm{NaCl}$ (phosphate buffered saline) containing $0.01 \%$ Tween 20 and $0.02 \% \mathrm{Na}$ azide. The first $350-\mathrm{ml}$ eluate was discarded, and the second $80-\mathrm{ml}$ eluate kept. This CSF solution was concentrated to about $10 \mathrm{ml}$ by ultrafiltration and stored in small portions at $-20^{\circ} \mathrm{C}$. The final yield of CSF was $8.2 \%$ of the starting activity. Other conditions for the purification procedures were similar to those reported previously (22).

CSF assay. Male $\mathrm{C} 3 \mathrm{H} / \mathrm{He}$ mice about 5 months old were used for all the experiments. One hundred thousand cells of femoral marrow were plated in separate $35-\mathrm{mm}$ plastic petri dishes (Lux) as a single-cell suspension in $1 \mathrm{ml}$ of McCoy's $5 \mathrm{~A}$ medium containing $0.32 \%$ agar, 20\% horse serum (Gibco) and an appropriate amount of CSF. The inoculated dishes were incubated for 7 days at $37^{\circ} \mathrm{C}$ under humidified air containing $5 \%$ carbon dioxide. The number of colonies ( 50 cells or more) was counted microscopically at the end of incubation. One unit of CSF is the activity that produces one such colony in the culture.

CSF activity also could be detected by the cellular uptake of radioactive thymidine. Bone marrow cells together with an appropriate amount of the CSF solution were suspended at a density of $2 \times 10^{5} / \mathrm{ml}$ in McCoy's 5 A medium containing $20 \%$ horse serum, then $0.5-\mathrm{ml}$ portions were placed in plastic culture tubes (Nunclon N-1409) and the tubes incubated at $37^{\circ} \mathrm{C}$ for 5 days. Tritiated thymidine (Amershan, $5 \mu \mathrm{Ci} / \mathrm{nmol} / 250 \mu \mathrm{l}$ ) was added at $0.4 \mu \mathrm{Ci} /$ tube. Six hours later, the cells were suspended in the phosphate buffered saline containing $25 \mathrm{mM}$ EDTA and transferred to glass fibre filter paper (Whatman GF/F, $2.4 \mathrm{~cm}$ diameter) then washed with $5 \%$ trichloroacetic acid followed by methanol. The radioactivity retained on the filter was measured with a liquid scintillation spectrometer and corrected for the zero-time controls $(64 \mathrm{cpm} /$ tube). The incorporation of radioactivity in the acid-insoluble materials increased linearly in the range of $0-15,000 \mathrm{cpm} /$ tube with the increase of the added CSF activity.

Chromatography and electrophoresis of CSF. A column, $2.5 \times 70 \mathrm{~cm}$, was used for 
Sephadex G-150 chromatography. Phosphate buffered saline was used for the elution of $\mathrm{CSF}$ at a flow rate of $27 \mathrm{ml} / \mathrm{h}$.

Isoelectrofocussing was done as described previously (29). The CSF solution was dialyzed against $0.02 \%$ Tween and placed on $110 \mathrm{ml}$ of a $5-50 \%$ sucrose concentration gradient containing $0.1 \%$ Ampholine (LKB). Electrophoresis was continued for $48 \mathrm{~h}$ at 500 volt at $5^{\circ} \mathrm{C}$.

Concanavalin A (Con A) Sepharose was obtained from Pharmacia and packed in a column, $1 \times 5 \mathrm{~cm}$, after equilibration with $10 \mathrm{mM} \mathrm{Na}$-acetate buffer at $\mathrm{pH} 6.0$ containing $150 \mathrm{mM} \mathrm{NaCl}, 1 \mathrm{mM} \mathrm{CaCl}, 1 \mathrm{mM} \mathrm{MgCl}, 0.01 \%$ Tween 20 and $0.02 \% \mathrm{Na}$-azide. This acetate-buffered cocktail containing $50 \mathrm{mM} \alpha$-methyl-D-glucoside was used for the elution of bound glycoproteins.

Preparative discontinuous polyacrylamide gel-electrophoresis was carried out in Canalco Prep-Disc equipped with a $2 / 150$ column. The stacking and separating gels were both $4 \mathrm{ml}$ in volume and contained $7 \%$ acrylamide and $0.184 \%$ bisacrylamide. Electrophoresis buffer was prepared according to Williams and Reisfeld (32). Tween 20 was added at a final concentration of $0.01 \%$. Before the application of the CSF solution, the gel was electrophoresed for $1 \mathrm{~h}$ to remove soluble materials. The CSF solution was dialyzed against $0.05 \mathrm{M}$ Tris$\mathrm{HCl}$ ( $\mathrm{pH} 5.5$ ) containing $0.01 \%$ Tween $20,3 \%$ sucrose and a trace of brom phenol blue, then a $2.25-\mathrm{ml}$ portion was applied to the column. The eluate was collected for $7 \mathrm{~h}$ in $12.6 \mathrm{ml}$ portions during electrophoresis at $8^{\circ} \mathrm{C}$ with a constant current of $10 \mathrm{~mA}$ and 1,100 volts.

Other methods. The sedimentation coefficient of the CSF was determined by the measurement of the distance of migration of the peak of CSF activity through a $5-50 \%$ sucrose concentration gradient, as reported previously $(29,31)$. After $0.2 \mathrm{ml}$ of the CSF solution had been layered on the top of $5 \mathrm{ml}$ of the gradient, it was centrifuged for $17 \mathrm{hr}$ at $5-\mathrm{C}$. Fractions of $0.23 \mathrm{ml}$ each were collected from the bottom of the tube and used to locate the peak CSF activity on the gradient.

Sodium periodate $(18 \mathrm{mM})$ was dissolved in $0.2 \mathrm{M} \mathrm{Na}$-acetate buffer at $\mathrm{pH} 5.0$. One tenth milliliter of this solution was added to $0.8 \mathrm{ml}$ of the CSF solution. The reaction was allowed to proceed at $4{ }^{\circ} \mathrm{C}$ in the dark for $0-18 \mathrm{~h}$ and was stopped by the addition of $0.1 \mathrm{ml}$ of $50 \%$ sucrose solution.

Anti-L cell CSF rabbit serum was a gift from Dr. E.R. Stanley of the Albert Einstein College of Medicine, New York City. It was used after it had been heated at $56^{\circ} \mathrm{C}$ for 30 min and diluted 120-fold with McCoy's 5A medium.

$\mathrm{L} \cdot \mathrm{P} 3$ cell CSF was partially purified by precipitation by ammonium sulphate. The specific activity of this preparation was about $2.5 \times 10^{4}$ units $/ \mathrm{mg}$ protein; nearly comparable to that of the Peak-1 CSF of the YSSF cells.

\section{RESULTS}

Chromatographic behaviour of the YSSF-cell CSF. In a separate experiment, all CSF activity was precipitated by ammonium sulphate from the serum-free conditioned medium, and a sample of it (216 mg protein) was chromatographed on Sephadex G-150. A major part of the CSF activity was eluted as a peak with the $\mathrm{V} / \mathrm{V}_{0}$ value of 2.20 (Fig. 1). The position of the peak was nearly the same for the agar colony assay and the $\left[{ }^{3} \mathrm{H}\right]$ thymidine uptake assay. Chymotrypsinogen (molecular weight-22,500) was eluted from this gel-filtration column with the $\mathrm{V} / \mathrm{V}_{0}$ value of 2.22 , indicating that the molecular weight of this major peak CSF is similar to that of chymotrypsinogen. In addition to the major peak, a few minor peaks were detected 


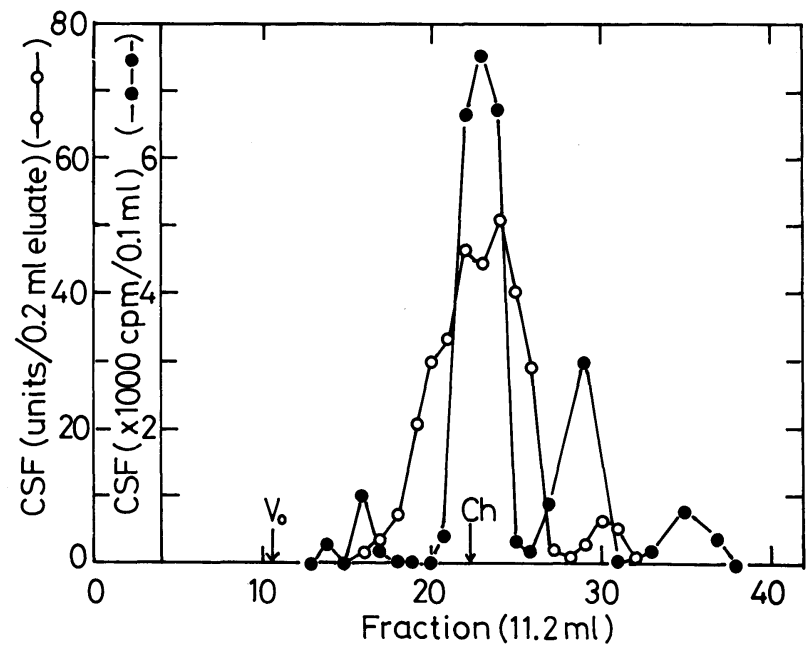

Fig. 1. Sephadex G-150 column chromatography of YSSF-cell CSF. See the text for details of the chromatography. Both the agar-colony and $\left[{ }^{3} \mathrm{H}\right]$ thymidine-uptake assays were done in duplicate with $0.2-\mathrm{ml}$ and $0.1-\mathrm{ml}$ portions of the eluate, respectively. Arrows $\mathrm{V}_{\mathrm{o}}$ and $\mathrm{Ch}$ show the positions of the peaks of blue dextran and chymotrypsinogen in separate runs. The total CSF activity recovered was about $70 \%$ based on the agar-colony assay.

by the $\left[{ }^{3} \mathrm{H}\right]$ thymidine uptake assay. The second largest peak was eluted with the $\mathrm{V} / \mathrm{V}_{0}$ value of 2.76; this value did not match that of the small peak of CSF activity detected by the agar colony assay method.

To prepare Peak-1 CSF, another large batch of ammonium sulphate precipitate was chromatographed through DEAE-cellulose as described in MATERIALS AND METHODS. The first CSF peak represented about one tenth of the total CSF activity. This material was chromatographed on Ultro-gel AcA44 chromatography and was recovered from the fraction that had an average $\mathrm{V} / \mathrm{V}_{0}$ value of 1.43 , which value was

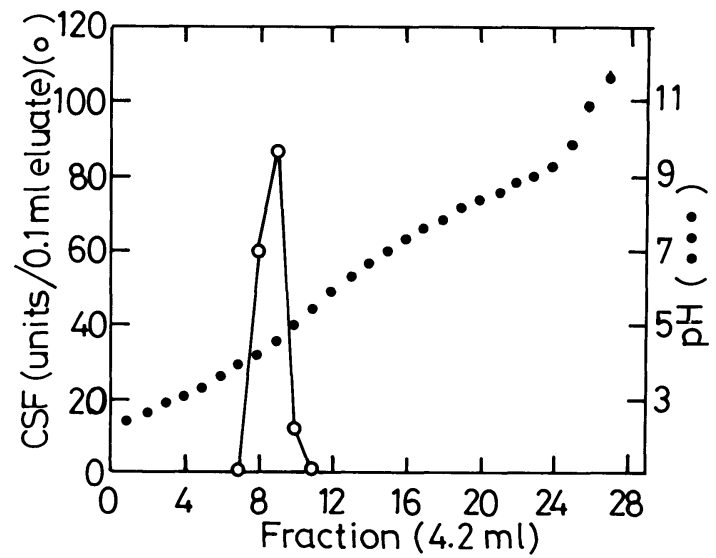

Fig. 2. Isoelectrofocussing of Peak-1 CSF from the YSSF-cell. CSF activity was assayed in duplicate with $0.1-\mathrm{ml}$ portions of each fraction after dialysis. The total CSF activity recovered was about $85 \%$. 


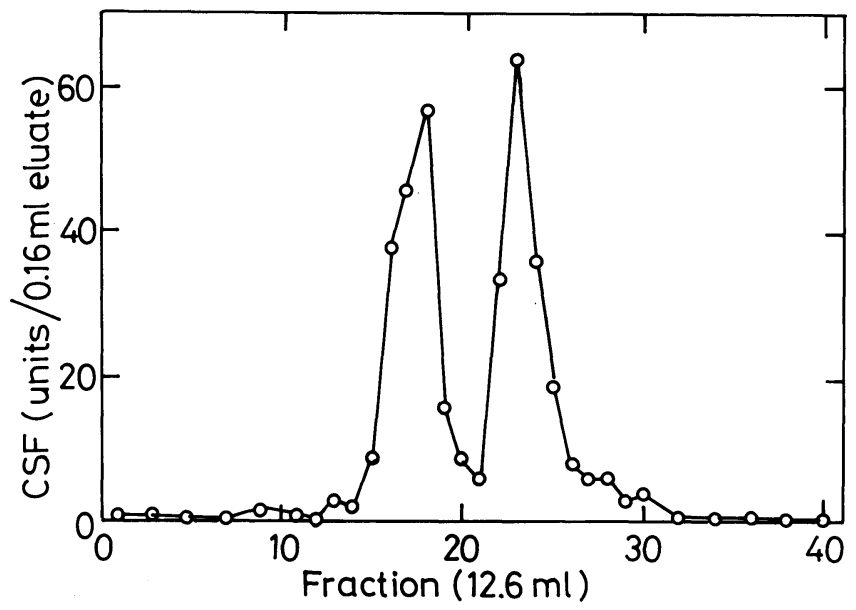

Fig. 3. Preparative polyacrylamide gel-electrophoresis of the Con A Sepharose unbound fraction of Peak-1 CSF. A $0.8-\mathrm{ml}$ sample of each fraction was mixed with $0.2 \mathrm{ml}$ of bovine serum albumin solution $(2.5 \mathrm{mg} / \mathrm{ml})$ then dialyzed overnight against excess saline. A $0.2-\mathrm{ml}$ portions of the dialyzate was used for the duplicate CSF assays. See Materials and Methods for details of electrophoresis.

consistent with a previous result (22). This elution position from the Ultro-gel column corresponded to a molecular weight of 22,000 , determined with bovine serum albumin, lactoglobulin, and cytochrome $\mathrm{c}$ as standards. This two-step-purified Peak-1 CSF was stored and used for the experiments reported below.

A sample $(0.31 \mathrm{mg}$ protein $)$ of the purified stock was used to determine the sedimentation coefficient of the CSF. Upon centrifugation in the sucrose density gradient, the CSF activity sedimented at a distance of $10.5 \mathrm{~mm}$ in $17 \mathrm{~h}$ as a single peak. This peak corresponded to a coefficient of $2.3 \mathrm{~S}$, or to a molecular weight of 21,000 .

Another sample $(0.31 \mathrm{mg}$ protein) of the stock was put through isoelectric focussing with the carrier Ampholine. The CSF activity was focussed at $\mathrm{pH} 4.5$ as a single peak (Fig. 2).

The major part (12.4 mg protein) of the stock was applied to a Con A Sepharose column. A total of $2.8 \mathrm{mg}$ or $22.5 \%$ of the applied protein was recoverd in the

TABLE 1. Heat STABILITy OF YSSF-Cell CSF AND L-P3-CELl CSF

\begin{tabular}{|c|c|c|c|}
\hline \multirow[b]{2}{*}{ Temperature } & \multicolumn{3}{|c|}{ CSF activity (colonies/dish) ${ }^{\mathrm{a}}$} \\
\hline & $\begin{array}{l}\text { YSSF-cell- } \\
\text { conditioned } \\
\text { medium }\end{array}$ & $\begin{array}{l}90 \%\left(\mathrm{NH}_{4}\right)_{2} \mathrm{SO}_{4} \\
\text { precipitate of } \\
\text { YSSF-cell CM }\end{array}$ & $\begin{array}{l}90 \%\left(\mathrm{NH}_{4}\right)_{2} \mathrm{SO}_{4} \\
\text { precipitate of } \\
\mathrm{L} \cdot \mathrm{P} 3 \text {-cell CM }\end{array}$ \\
\hline Control $\left(5^{\circ} \mathrm{C}\right)$ & $61(100)^{b}$ & $95(100)$ & $98(100)$ \\
\hline $60^{\circ} \mathrm{C}, 30 \mathrm{~min}$ & $46(75)$ & $93(98)$ & $90(92)$ \\
\hline $60^{\circ} \mathrm{C}, 60 \mathrm{~min}$ & n.d. & $104(109)$ & $86(88)$ \\
\hline $100^{\circ} \mathrm{C}, 5 \mathrm{~min}$ & $26(43)$ & $71(75)$ & $23(23)$ \\
\hline
\end{tabular}

a CSF solutions were dialyzed against phosphate buffered saline, then appropriately diluted and heated in 2-ml portions as above. Samples of these solutions $(0.1 \mathrm{ml})$ were assayed for CSF activity in each 1-ml bone marrow cell culture. Figures in the table are the averages of three dishes.

${ }^{\mathrm{b}}$ Figures in parentheses represent CSF activity as a percentage of the respective control. 


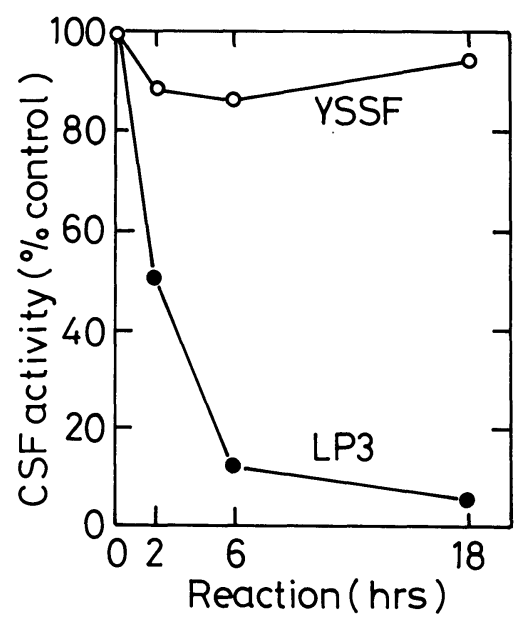

Fig. 4. Loss of CSF activity by treatment with periodate. See MATERIALS AND Methods for details. After the reaction, the CSF solution was dialyzed against phosphate-buffered saline, and $0.1-\mathrm{ml}$ portions were used for the colony assay. Data shown in the figure are averages of two dishes. Controls: YSSF-cell CSF-105 colonies/dish; L·P3 cell CSF-214 colonies/dish.

fraction not bound to the column. This break-through fraction contained more than $84 \%$ of the applied CSF activity. The other $16 \%$ of the CSF activity was found in the fraction eluted from the column with $\alpha$-methyl-D-glucoside. A large sample $(2.70 \mathrm{mg}$ protein) of the unbound fraction was put through preparative polyacrylamide gel electrophoresis. The CSF was resolved into two peaks of similar size as shown in Fig. 3.

Other properties of the YSSF-cell CSF. The heat-stability of the YSSF-cell CSF in the crude preparations is shown in Table 1 . The CSF activity precipitated with

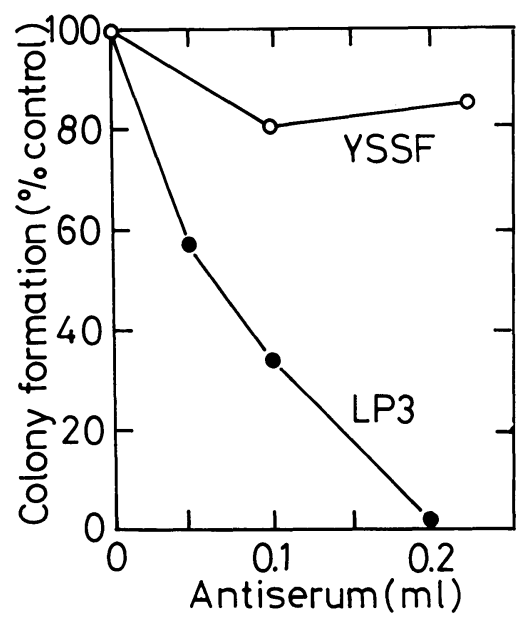

Fig. 5. Inhibition of CSF activity by the addition of anti-L cell CSF serum (120-fold dilution) to the bone marrow cell culture. Controls: YSSF-cell CSF-62 colonies/dish; L-P3-cell CSF56 colonies/dish. 
ammonium sulphate seems to be more stable than that in the original cell-conditioned medium. Exposure of the crude CSF to acidic $(\mathrm{pH} 2.0$ by $\mathrm{HCl})$ and basic $(\mathrm{pH} 11.5$ by $\mathrm{NaOH}$ ) environments resulted in $48 \%$ or $78 \%$ loss of activity within $2 \mathrm{~h}$ at room temperature. Peak-1 CSF also was fairly stable; nearly $100 \%$ of the activity was recovered after the crude preparation was filtered through an Ultro-gel AcA44 column as well as when it was chromatographed on Con A Sepharose. The L·P3-cell CSF was slightly less stable than the YSSF-cell CSF (Table 1).

Oxidation with periodate showed a significant difference in the stability of the L.P3-cell CSF and the Peak-1 CSF of the YSSF cells (Fig. 4). Nearly all the activity of the L.P3-cell CSF was lost by an 18-h treatment with $2 \mathrm{mM}$ periodate, whereas loss of the YSSF-cell CSF activity during the same treatment was negligible.

An addition of anti-L cell CSF serum to a soft-agar culture of bone marrow

TABLE 2. MOlecular Weight of THREe Classes OF CSF estimated BY GEL-FILTRATION CHROMATOGRAPHY

\begin{tabular}{|c|c|c|c|c|}
\hline \multirow{2}{*}{ Sources } & \multicolumn{3}{|c|}{ Molecular weight estimate ${ }^{a}$} & \multirow{2}{*}{ Rf. } \\
\hline & G-CSF & GM-CSF & M-CSF & \\
\hline \multirow[t]{2}{*}{ Human placenta $\mathrm{CM}$} & $30,000(\mathrm{G}-150)^{\mathrm{b}, \mathrm{c}}$ & & & 4 \\
\hline & 27,000 (AcA44) & & $41,000(\mathrm{AcA} 44)$ & 34 \\
\hline MIA PaCa cell CM & $27,000(\mathrm{AcA} 44)$ & & $50,000(\mathrm{AcA} 44)$ & 35 \\
\hline T3M-1 cell CM & $30,000(\mathrm{G}-75)$ & & & 23 \\
\hline RSP-2 $\cdot$ PC cell CM & & $20,000(\mathrm{HW} 55 \mathrm{~F} / \mathrm{G})^{\mathrm{d}}$ & & 30 \\
\hline YSSF-212T cell CM & & 22,000 (AcA44) & & 22 \\
\hline Post-LPS tissue extracts & & $23,000(\mathrm{CL} 6 \mathrm{~B} / \mathrm{G})^{\mathrm{d}}$ & & 21 \\
\hline \multirow[t]{2}{*}{ T-cell hybridoma CM } & & $24,000(\mathrm{AcA} 44)$ & & 6 \\
\hline & & $35,000(\mathrm{~S}-200)$ & & 12 \\
\hline Mouse lung CM & & $29,000(\mathrm{AcA} 44)$ & & 3 \\
\hline Mo cell CM & & 34,000 (AcA44) & & 17 \\
\hline GCT cell CM & & $35,000(\mathrm{~S}-200)$ & & 8 \\
\hline \multirow[t]{2}{*}{ PWM-spleen cell CM } & & $37,000(\mathrm{G}-150)$ & & 5 \\
\hline & & $24,000(\mathrm{CL} 6 \mathrm{~B} / \mathrm{G})^{\mathrm{d}}$ & & 5 \\
\hline Human T-cell CM & & $40,000(\mathrm{G}-150)$ & & 33 \\
\hline Human lung CM & & $\underline{41,000}(\mathrm{AcA} 44)$ & & 9 \\
\hline Mouse yolk sac CM & & & $60,000(\mathrm{G}-100)$ & 13 \\
\hline L-cell CM & & & $73,000(\mathrm{G}-150)$ & 1 \\
\hline \multirow[t]{2}{*}{ Human urine } & & & $75,000(\mathrm{G}-100)$ & 16 \\
\hline & & & $85,000(\mathrm{G}-150)$ & 20 \\
\hline \multirow[t]{2}{*}{$\mathrm{L} \cdot \mathrm{P} 3$ cell $\mathrm{CM}$} & & & 80,000 (AcA34) & 29 \\
\hline & & & 47,000 (HW55F/G) & 30 \\
\hline
\end{tabular}

a In much of the literature cited, the molecular weight estimate is given as a range. Median values have been used in this table for simplicity.

b Column matrices used for gel-filtration chromatography are shown in parentheses; G-75, G-100, G-150-Sephadex; AcA34, AcA44-Ultro-gel; S-200-Sephacryl; HW55F/G-Toyo-Pearl HW55F run in the presence of $6 \mathrm{M}$ guanidine; CL6B/G-Sepharose CL-6B run in the presence of $6 \mathrm{M}$ guanidine.

c Underlined estimates are those of CSFs known to be effective toward human stem cells.

d Analysis after neuraminidase treatment. 
cells significantly decreased the number of cell colonies when L·P3-cell CSF was used to stimulate cells of monocyte/macrophage lineage.

Granulocyte/macrophage colony formation by Peak-1 CSF of the YSSF cells, however, was not much affected by the anti-L cell CSF serum (Fig. 5). Microscopic examination of the cell colonies showed that there was no selective change in cell morphology in the presence of the antiserum.

\section{DISCUSSION}

Results of gel-filtration chromatography, Sephadex G-150 and Ultro-gel AcA44, and the measurement of sedimentation coefficient suggested that the YSSF-cell Peak-1 CSF has a molecular weight of about 22,000. Molecular weight estimates of three classes of CSF from various sources are given in Table 2. The YSSF-cell CSF is one of the smallest of these CSFs. Since all these CSFs presumably are sialoglycoproteins, their behaviour in gel-filtration chromatography does not precisely reflect their molecular weight. Nevertheless, GM-CSF seems to be generally smaller than M-CSF, the difference between GM-CSF and M-CSF shown in Table 2 being statistically significant $(\mathrm{P}<1 \%)$. In contrast, the difference between G-CSF and GM-CSF is not as great as the difference between M-CSF and GM-CSF.

Molecular heterogeneity has been found for many kinds of CSF. This also was true for the YSSF CSF. Peak-1 CSF was contained in the fraction that bound to the DEAE-cellulose most loosely. As reported previously (22), a large part of the total CSF remained bound on the column under the conditions that eluted Peak-1 CSF. Therefore, Peak-1 CSF seems to be least heavily sialylated of the several homologous CSFs of the YSSF cells. Although Peak-1 CSF behaved as a single peak both in gelfiltration chromatography and in isoelectrofocussing, it was resolved into two components by subsequent polyacrylamide gel-electrophoresis. Probably, a slight

TABLE 3. ISOELECTRIC POINTS OF THREE CLASSES OF CSF

\begin{tabular}{|c|c|c|c|c|}
\hline \multirow{2}{*}{ Sources } & \multicolumn{3}{|c|}{ Isoelectric point ${ }^{\mathrm{a}}$} & \multirow{2}{*}{ Rf. } \\
\hline & G-CSF & GM-CSF & M-CSF & \\
\hline Human placenta $\mathrm{CM}$ & $5.7^{\mathrm{b}}$ & & 4.2 & 34 \\
\hline MIA PaCa cell CM & 5.7 & & 4.2 & 35 \\
\hline Human lung $\mathrm{CM}$ & & $3.8(4.3)^{\mathrm{c}}$ & & 9 \\
\hline Mo cell $\mathrm{CM}$ & & $4.0(4.6)$ & & 17 \\
\hline T-cell hybridoma CM & & $\overline{4.3}$ & & 6 \\
\hline RSP-2.P3 cell CM & & 4.4 & & 30 \\
\hline YSSF-212T cell CM & & 4.5 & & d \\
\hline PWM-spleen cell CM & & $\overline{4.8}$ & & 5 \\
\hline Human urine & & & $3.3(4.5)$ & 14 \\
\hline $\mathrm{L} \cdot \mathrm{P} 3$ cell $\mathrm{CM}$ & & & $3.5(5.4)$ & 29 \\
\hline L60T cell CM & & & 4.3 & 27 \\
\hline
\end{tabular}

a Median values of the $\mathrm{pI}$ ranges reported in the literature.

b Underlined values are those of CSFs known to be effective toward human stem cells.

c Figures in parentheses are isoelectric points of the CSFs after treatment with neuraminidase. Information on the pI of neuraminidase-treated CSFs was not available for all the CSFs listed.

d Present paper. 
difference in the molecular properties of the two components resulted in their separation by the most sensitive method. A similar microheterogeneity recently was reported by Burgess et al. (7) for the epidermal growth factor from mouse submaxillary gland. In our study, however, the possibility can not be excluded that the microheterogeneity may have been artificially induced during electrophoresis.

The heterogeneity of our CSF seems mainly to be due to the molecule being a sialoglycoprotein $(2,26,31)$. Variations in the isoelectric points of the various CSFs are shown in Table 3. Probably the diversity of molecular charges of the CSFs from different sources also is due to the degree of sialylation. Although our information is limited, M-CSF seems to be more heavily sialylated than GM-CSF.

Desialylation of human urine and L.P3-cell M-CSF increased their isoelectric points by more than one $\mathrm{pH}$ unit, whereas the shift in $\mathrm{pI}$ was only a one-half $\mathrm{pH}$ unit in the GM-CSFs from human lung and Mo-cell CM.

Tables 2 and 3 also show which CSFs are active on human cells. Generally speaking, the CSFs that are not specific for animal species are small and less acidic than speciesspecific CSF. Alternatively, it can be said that the granulopoietic pathway is less dependent on species difference than the monocyte/macrophage pathway.

Acknowledgements. We thank Dr. B. Tamaoki, Director of the Division of Pharmaceutical Science of our Institute for his interest and encouragement. Thanks also are due to Miss F. Miyanaga and Miss S. Inoue for their skillful technical assistance. This study was supported in part by a Grant-in-Aid for Cancer Research from the Ministry of Education, Science and Culture of Japan and in part by a grant from the Science and Technology Agency, Japan.

\section{REFERENCES}

1. Austin, P.E., E.A. McCulloch and J.E. Till. Characterization of the factor in L-cell conditioned medium capable of stimulating colony formation by mouse marrow cells in culture. J. Cell Physiol. 77, 121-134, 1971

2. Ayusawa, D., K. Isaka, T. Seno, M. Tomida, Y. Yamamoto, M. Hozumi, A. Takatsuki and G. TAMURA. Effect of tunicamycin on molecular heterogeneity of colony stimulating factor in cultured mouse mammary carcinoma FM3A cells. Biochem. Biophys. Res. Comm. 90, 783787, 1979

3. Burgess, A.W., J. Camakaris and D. Metcalf. Purification and properties of colony-stimulating factor from mouse lung-conditioned medium. J. Biol. Chem. 252, 1998-2003, 1977

4. Burgess, A.W., E.M.A. Wilson and D. Metcalf. Stimulation by human placental conditioned medium of hemopoietic colony formation by human marrow cells. Blood 49, 573-583, 1977

5. Burgess, A., D. Metcalf, S.H.M. Russell and N.A. Nicola. Granulocyte/macrophage, megakaryocyte, eosinophil and erythroid colony-stimulating factors produced by mouse spleen cells. Biochem. J. 185, 301-314, 1980

6. Burgess, A.W., P.F. Bartlett, D. Metcalf, N.A. Nicola, I. Clark-Lewis and J.W. SCHRADER. Granulocyte-macrophage colony-stimulating factor produced by an inducible murine T-cell hybridoma. Molecular properties and cellular specificity. Exp. Hematol. 9, 893903, 1981

7. Burgess, A.W., J. Knesel, L.G. Sparrow, N.A. Nicola and E.C. Nice. Two forms of murine epidermal growth factor: Rapid separation by using reverse-phase HPLC. Proc. Natl. Acad. Sci. U.S.A. 79, 5753-5757, 1982

8. DiPersio, J.F., J.K. Brennan, M.A. Lichtman and B.L. Speiser. Human cell lines that elaborate colony-stimulating activity for the marrow cells of man and other species. Blood 51, 507-519, 1978 
9. Fojo, S.S., M.-C. Wu, M.A. Gross, Y. Purcell and A.A. Yunis. Purification and characterization of a colony stimulating factor from human lung. Biochemistry 17 3109-3115, 1978

10. Heard, J.M., S. Fichelson and B. Varet. Role of colony-stimulating activity in murine long-term bone marrow cultures: Evidence for its production and consumption by the adherent cells. Blood 59, 761-767, 1982

11. Horiuchi, M., K. Nagata and Y. IChiKawa. "Determination" of differentiation of bipotent hemopoietic progenitor cells in vitro. Exp. Cell Res. 123, 247-252, 1979

12. Howard, N., A. Burgess, D. MCPhee and D. Metcalf. T-cell hybridoma secreting hemopoietic regulatory molecules: Granulocyte-macrophage and eosinophil colony-stimulating factors. Cell 18, 993-999, 1979

13. Johnson, G.R. and A.W. Burgess. Molecular and biological properties of a macrophage colony-stimulating factor from mouse yolk sacs. J. Cell Biol. 77, 35-47, 1978

14. Kellar, K.L., W.R. Vogler and J.M. Kinkase, Jr. Colony stimulating factor (CSF) from human leukemic urine: Affinity chromatography and isoelectric focusing. Proc. Soc. Exp. Biol. Med. 150, 766-772, 1975

15. Lanotte, M., D. Metcalf and T.M. Dexter. Production of monocyte/macrophage colonystimulating factor by preadipocyte cell lines derived from murine marrow stroma. J. Cell. Physiol. 112, 123-127, 1982

16. Laukel, H., W.D. Gassel, H.M. Dosch, W. Schmidt and K. Havemann. Preparation of colony stimulating activity from large batches of human urine and production of antisera against it. J. Cell. Physiol. 94, 21-30, 1978

17. Lusis, A.J., D.H. QuON and D.W. Golde. Purification and characterization of a human Tlymphocyte derived granulocyte-macrophage colony-stimulating factor. Blood 57, 13-21, 1981

18. Newton, I.A., J. Metral, G. Hurdy-Clergeon, R. Berthier, A. Lajmanovich, A. Schweitzer, E. Chagnon and D. Hollard. Similarity of CSF of media conditioned by different human tissues. Exp. Hematol. 10, 196-205, 1982

19. Metcalf, D. Clonal analysis of proliferation and differentiation of paired daughter cells: Action of granulocyte-macrophage colony-stimulating factor on granulocyte-macrophage precursors. Proc. Natl. Acad. Sci. U.S.A. 77, 5327-5330, 1980

20. Motoyoshi, K., F. Takaku, H. Mizoguchi and Y. Miura. Purification and some properties of colony-stimulating factor from normal human urine. Blood 52, 1012-1020, 1978

21. Nicola, N.A., A.W. Burgess and D. Metcalf. Similar molecular properties of granulocytemacrophage colony-stimulating factors produced by different mouse organs in vitro and in in vivo. J. Biol. Chem. 254, 5290-5299, 1970

22. Ohno, T., M. Seki and M. Shikita. Colony-stimulating factors active on human bone marrow cells from a Yoshida sarcoma cell line. Blood 51, 911-918, 1978

23. Окаве, T., H. Nomura, N. Sato and N. OhSAWA. Large-scale preparation and characterization of human colony-stimulating factor. J. Cell. Physiol. 110, 43-49, 1982

24. Schwartz, R.S. and P.L. Greenberg. Stromal colony-stimulating activity production and myeloid colony-forming cells in human hemopoietic and nonhemopoietic bone marrow. Blood, 57, 771-780, 1981

25. Sheridan, J.W. and E.R. Stanley. Tissue sources of bone marrow colony stimulating factor. J. Cell. Physiol. 78, 451-460, 1971

26. Stanley, E.R. and D. Metcalf. The molecular weight of colony-stimulating factor (CSF). Proc. Soc. Exp. Biol. Med. 137, 1029-1031, 1971

27. Stanley, E.R. and P.M. Heard. Factors regulating macrophage production and growth. Purification and some properties of the colony stimulating factor from medium conditioned by mouse L cells. J. Biol. Chem. 252, 4305-4312, 1977

28. Stanley, E.R. and L.J. Guilbert. Methods for the purification, assay, characterization and target cell binding of a colony stimulating factor (CSF-1). J. Immunol. Methods 42, 253-284, 1981

29. TsuneokA, K. and M. Shikita. A sialoglycoprotein stimulating proliferation of granulocytemacrophage progenitors in mouse bone marrow cell cultures. FEBS Lett. 77, 243-246, 1977 
30. Tsuneoka, K. and M. Shikita. Production of granulocyte-macrophage colony-stimulating factors (GM-CSF) by various mammalian cell lines cultured in a protein-free synthetic medium. Cell Struct. Funct. 5, 315-321, 1980

31. Tsuneoka, K., M. Shikita, A. Takatsuki and G. Tamura. A colony-stimulating factor produced by mouse L·P3 cells in the presence of tunicamycin or 2-deoxy-D-glucose. J. Biochem. 90, 611-618, 1981

32. Williams, D.E. and R.A. Reisfeld. Disc electrophoresis in polyacrylamide gels: Extension to new conditions of pH and buffer. Ann. N.Y. Acad. Sci. 121, 373-381, 1964

33. Wu, A.M. Properties and separation of $\mathrm{T}$ lymphocyte growth stimulatory activity (TL-GSA) and of granulocyte-macrophage colony stimulatory activity (GM-CSA) produced separately from two human T-lymphocyte subpopulations. J. Cell. Physiol. 101, 237-250, 1979

34. Wu, M.-C. and R.A. Fischer. Granulocyte and macrophage colony-stimulating factor from human placenta conditioned medium. Biochemistry 19, 3846-3850, 1980

35. WU, M.-C. and A.A. YUNIS. Common pattern of two distinct types of colony-stimulating factor in human tissues and cultured cells. J. Clin. Invest. 65, 772-775, 1980

36. Yamane, I., O. MuraKami and M. Kato. "Serum-free" culture of various mammalian cells and the role of bovine albumin. Cell Struct. Funct. 1, 279-284, 1976

(Received for publication, March 23, 1983) 